\title{
TOLLIP wt Allele
}

National Cancer Institute

\section{Source}

National Cancer Institute. TOLLIP wt Allele. NCI Thesaurus. Code C52440.

Human TOLLIP wild-type allele is located in the vicinity of 11 p15.5 and is approximately 35

$\mathrm{kb}$ in length. This allele, which encodes toll-interacting protein, plays a role in the

modulation of both interleukin and toll-like receptor signal transduction. 